\title{
Pakistan: Breaking Out of Stagflation into Sustained Growth
}

\author{
Rashid Amjad*, Musleh ud Din ${ }^{* *}$, and Abdul Qayyum ${ }^{* * *}$
}

\begin{abstract}
This paper proposes that the underlying cause of the macroeconomic problems facing Pakistan today are a series of supply shocks which have constrained output growth. It is argued that while the current debate has solely focused on government expenditures and revenues, it is critical to also address the acute energy shortages which is constraining supply. The paper goes on to present four recommendations for breaking out of the present stagflation: (i) prudent macroeconomic management, (ii) reviving the role of the government in development while restoring fiscal balance, (iii) loosening monetary policy in order to spur the private sector, and (iv) improving social safety nets.
\end{abstract}

Keywords: Economic Growth, Supply Shock, Pakistan.

\section{JEL Classification: F43, P44.}

\section{Introduction}

As far back as the 1950s, Pakistan's economic growth has been characterized by stop-go cycles. Periods of high economic growth, sparked in many cases by increases in foreign resource inflows, have been followed by a sharp slowdown as foreign resource inflows dried up, resulting in unsustainable current account and fiscal deficits that dictated deflationary measures.

\footnotetext{
${ }^{*}$ Vice-Chancellor, Pakistan Institute of Development Economics (P.I.D.E), Islamabad. ** Joint Director, Pakistan Institute of Development Economics (P.I.D.E), Islamabad.

${ }^{* * * *}$ Registrar, Pakistan Institute of Development Economics (P.I.D.E), Islamabad.
} 
Figure 1: Pakistan's Macroeconomic Performance

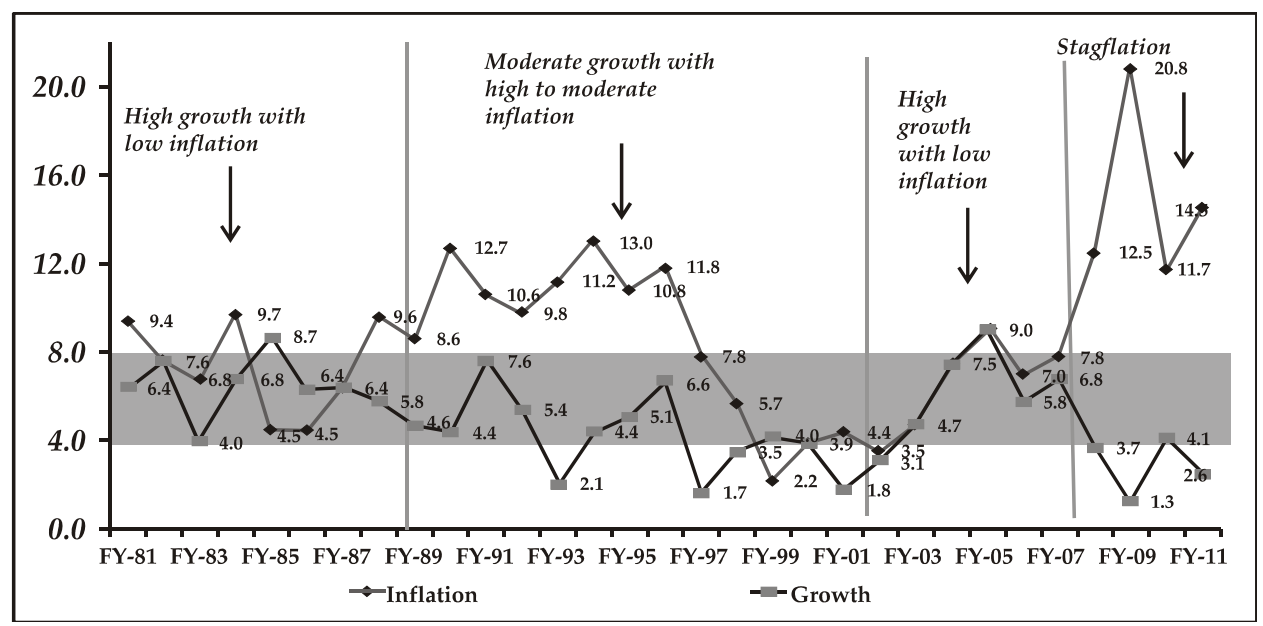

Source: Government of Pakistan. (n.d.). Pakistan Economic Survey (Various issues). Islamabad.

As can be seen from Figure 1,1 Pakistan has over the last 30 years experienced periods of high economic growth with low inflation followed by low economic growth with low to moderate inflation (or variants of this combination). It is important to note here that spurts of high economic growth since 1980 have taken place when inflation levels were generally low. Starting in 2007/08, the economy has, over the last four years, witnessed a new phenomenon-very low economic growth with very high double-digit inflation, a situation classically described as stagflation.

The main aim of this study is to identify the factors that are responsible for this continuing stagflation, and new policy measures needed to break out of this undesirable situation. The thrust of the analysis is on understanding the macroeconomic dynamics of this continuing stagflation, which could form the basis of the remedial measures being proposed.

The fundamental proposition being put forward is that, while the underlying cause of this crisis still lies in the economy's basic structural weaknesses and lack of political will to carry out much needed economic

\footnotetext{
1 The two bands shown in Figure 1 represent the lower side of minimum economic growth (4 percent) that would ensure at least some increase in per capita income, given Pakistan's population growth rate, which is estimated at just over 2 percent. (To avoid rising unemployment with a growth rate of 3 percent of the labour force would require a minimum growth of around 6 percent.) The upper band (8 percent) represents the average inflation rate for the entire period. Pakistan, with the exception of the recent past, has very seldom experienced double-digit inflation.
} 
reforms, the major cause of this current stagflation is a series of supply shocks (acute energy shortages, rising global oil prices, and unprecedented floods in the summer of 2010). These supply shockswhich have pushed the supply curve upward, seriously constraining output growth-when combined with rising demand pressures (high fiscal deficits financed by direct borrowings from the State Bank of Pakistan (SBP), large increases in remittances, high governmentsupported cereal prices, and large increases in the wages of public sector employees) have unleashed high inflation. In these conditions, both unemployment and poverty levels must have risen.

The article goes on to argue that, while the current and almost sole emphasis in the policy debate on raising revenues and curbing the fiscal deficit is well justified, this in itself will not be sufficient. Equally important is solving or easing the real binding constraint to the supply side of acute energy shortages, which are crippling the economy, especially manufacturing, services, and the informal economy. We then propose a four-point strategy to tackle the current crisis and move the economy out of stagflation.

\section{The Economic Context}

A growing body of opinion (see Ahmed, 2011; Haque, 2010) traces the roots of the current crisis to many of the economic policies adopted by the last Musharraf government. These included in 2002/03 (i) the adoption of a loose monetary policy to jumpstart the economy; (ii) the lack of any serious attempt to undertake basic structural reforms or raise the tax/gross domestic product (GDP) ratio; and (iii) a policy of "inaction and neglect" in anticipating the emerging large gap in supply of and demand for energy, and failing to raise energy prices when the first oil shock hit; these measures were politically expedient as it was an election year. While the government implemented some desirable economic policies that spurred growth, on the whole they were not sufficient.

The Musharraf government appears to have been lulled into inaction, as previous governments had also been, by the massive increases in remittances and foreign inflows as well as the rescheduling of foreign debt and easier access to some (European Union) export markets for some time, following $9 / 11$. Growth was also mainly consumption-led and energy-intensive as cheap credit was made available to buy consumer durables, especially automobiles. Investment levels did increase (domestic and foreign) but were clearly still low, hovering at 
their peak at just over 20 percent of GDP, and were clearly insufficient to result in sustainable growth.

The economy, therefore, remained delicately balanced and vulnerable during the Musharraf period. With the very first external shock in 2006/07-the unprecedented increase in global oil and cereal prices-the economy began to flounder. This downturn in economic growth, which started in 2006/07, had by March 2008-when the new government took office-ballooned into a full-fledged economic crisis. The fiscal deficit estimated for 2007/08 (in March 2008) was 9 percent, the current account deficit was 8 percent of GDP, and falling foreign exchange reserves were declining by almost USD1 billion each month at the peak of the increase in global oil prices.

With foreign exchange reserves in early 2007 at only USD17 billion and fast declining, the new government had no choice but to opt for strong deflationary measures. When the government found that there were few "friends" who could bail it out, it had no recourse but to approach the International Monetary Fund (IMF). Indeed, even Pakistan's "friends" encouraged the government to seek IMF support as many felt that only it could provide the "strong arm" needed to ensure that the government would implement stabilization measures together with much needed economic reforms, especially the imposition of value-added tax (VAT) (later called the reformed general sales tax [RGST]). There was clearly a "trust deficit" between the new government and major donor countries.

That Pakistan suffered from weak macroeconomic fundamentals, which made it much more vulnerable, first, to the oil and commodity price shocks and then the financial crisis that followed, can be seen by comparing its performance to its neighbors in the South Asian Association for Regional Cooperation (SAARC) (Amjad \& Din, 2010). Pakistan fared far worse from the global financial crisis than India, Bangladesh, and Sri Lanka, and these countries also rebounded quickly to return to their earlier high growth path while Pakistan remained mired in stagflation (see Table 1). 


\section{Table 1: Macroeconomic Policies and Growth Reforms South Asia: Impact of the Financial Crisis GDP Growth Rates (\%)}

\begin{tabular}{lcccccccc}
\hline \multicolumn{1}{c}{ Country } & FY & FY & FY & FY & FY & FY & FY & FY \\
& $\mathbf{2 0 0 4}$ & $\mathbf{2 0 0 5}$ & $\mathbf{2 0 0 6}$ & $\mathbf{2 0 0 7}$ & $\mathbf{2 0 0 8}$ & $\mathbf{2 0 0 9}$ & $\mathbf{2 0 1 0}$ & $\mathbf{2 0 1 1}$ \\
\hline Bangladesh & 6.3 & 6.0 & 6.6 & 6.4 & 6.2 & 5.9 & 5.5 & 6.0 \\
India & 8.5 & 7.5 & 9.5 & 9.6 & 9.3 & 6.8 & 8.0 & 8.6 \\
Pakistan & 7.5 & 9.0 & 5.8 & 6.8 & 3.7 & 1.7 & 3.8 & 2.4 \\
Sri Lanka & 5.4 & 6.2 & 7.7 & 6.8 & 6.0 & 3.5 & 8.0 & 8.0 \\
\hline
\end{tabular}

FY = fiscal year, GDP = gross domestic product.

Sources: Bangladesh Economic Review, 2011; Economic Survey of India, 2009; Economic Survey of Pakistan, 2011; Economic Survey of Sri Lanka, 2009; Economic and Social Survey of Asia and the Pacific, 2011.

In all fairness it should be said that Pakistan has suffered, especially in the last three years, due to a fragile security situation and low-level insurgency resulting in considerable loss of both domestic and foreign business confidence. Also, the unprecedented floods in the summer of 2010 estimated at costing USD10 billion by a joint World Bank/Asian Development Bank study shaved off nearly 1 to 1.5 percent of expected growth, besides destroying badly required physical infrastructure.

Yet, as we shall argue, this difficult and challenging situation has been made worse by poor macroeconomic management and a serious lack of coordination in economic policymaking, especially by fiscal and monetary policy authorities.

\section{Supply Shocks and Stagflation ${ }^{2}$}

How a supply shock flowing from, say, an increase in oil prices or severe power shortages can result in stagflation is illustrated by the simple diagram below.

\footnotetext{
${ }^{2}$ There is a large body of literature on stagflation. During the 1960s and 1970s, stagflation in Latin American economies, with their peculiar characteristics (wide income and asset inequalities, the vast majority of the population living in urban areas, strong trade unions, and high dependence on the export of commodities) was widely debated. The jump in oil prices in the 1970s caused by Organization of Petroleum Countries (OPEC) also resulted in stagflation and, again, was subject to considerable analysis (see, for instance, Barsky \& Kilian, 2002; Blinder, 1981; Brunner, Cukierman, \& Meltzer, 1980; Bruno \& Sachs, 1979).
} 
Price

level

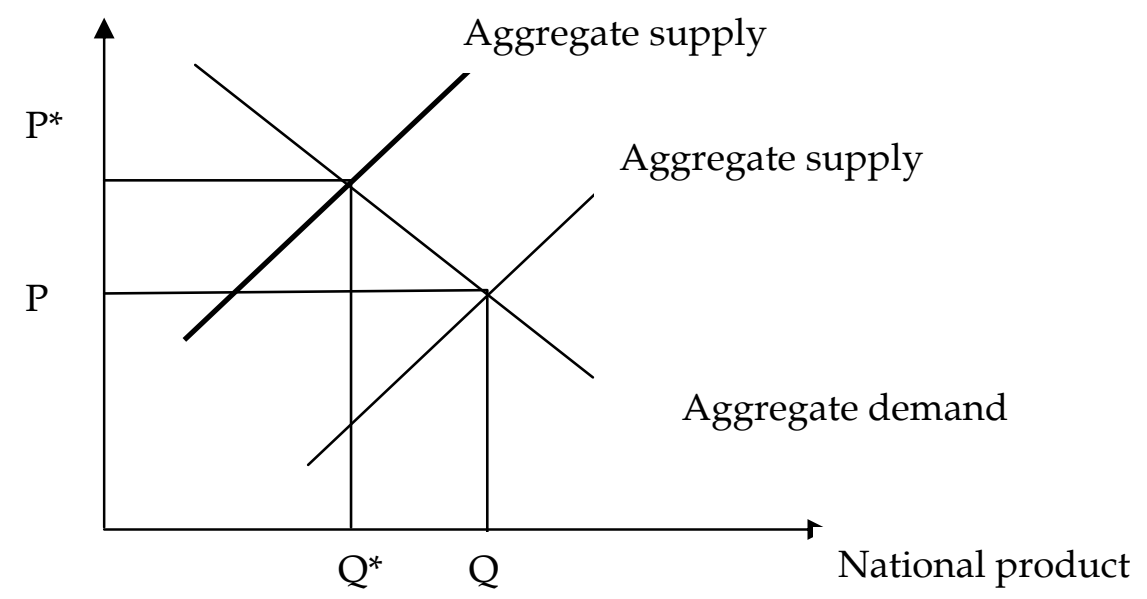

Aggregate demand and aggregate supply as shown above will result in output $Q$ and price level $P$. As the supply shock pushes the supply curve upward, output declines to $Q^{*}$ and the price level increases to $P^{*}$, with the extent of this price increase and output contraction depending on the intensity and magnitude of the supply shock.

If the resulting price increase is large, the monetary authorities can deflate the economy by tightening money supply and raising interest rates, thus pushing the aggregate demand downward. This could bring prices down but further accentuate the fall in output and deepen the recession.

If the government was to, however, counter the recession resulting from the upward shift in the supply curve by increasing aggregate demand, say, through a fiscal stimulus, then depending on peculiar economic conditions in the economy, this could result in much higher inflation without stimulating a corresponding increase in output. This would then result in a classical stagflation situation. The point to grasp is that, faced with an upward shift in the supply curve, policymakers face hard choices.

\section{Pakistan's Attempt at Stabilization}

That Pakistan had to stabilize its economy in early 2008, given its precarious and fast deteriorating macroeconomic situation, was never in 
doubt. $^{3}$ Although the IMF Stand-By Agreement (SBA) was signed in November 2008, a "shadow" IMF program had been agreed on earlier and was the basis on which the 2008/09 national budget was announced in June 2008.

The key elements of the 23-month SBA for special drawing rights (SDR) of USD7.3 billion in support of the macroeconomic stabilization program included the following (IMF, 2008):

- Under the fiscal program, it sought to reduce the deficit from 7.4 percent of GDP in 2007/08 to 4.2 percent in 2008/09 and 3.3 percent in 2009/11, while allowing for increased spending on a social safety net (through the Benazir Income Support Program [BISP]). This reduction was to be achieved by phasing out energy subsidies, reducing development expenditures, and raising tax revenues including through the introduction of a VAT and other tax and administration reforms.

- Monetary policy was to be tightened by raising interest rates from 13 to 15 percent.

- While not made explicit, the exchange rate was also to be suitably depreciated to ensure lost competitiveness over the last few years and compress imports.

Table 2: Movement of Key Economic Variables

\begin{tabular}{lcccccccc}
\hline \multicolumn{1}{c}{ Variable } & $\mathbf{F Y}$ & $\mathbf{F Y}$ & $\mathbf{F Y}$ & $\mathbf{F Y}$ & $\mathbf{F Y}$ & $\mathbf{F Y}$ & $\mathbf{F Y}$ & $\mathbf{F Y}$ \\
& $\mathbf{2 0 0 4}$ & $\mathbf{2 0 0 5}$ & $\mathbf{2 0 0 6}$ & $\mathbf{2 0 0 7}$ & $\mathbf{2 0 0 8}$ & $\mathbf{2 0 0 9}$ & $\mathbf{2 0 1 0}$ & $\mathbf{2 0 1 1}$ \\
\hline $\begin{array}{l}\text { Economic } \\
\text { growth }\end{array}$ & 7.5 & 9.0 & 5.8 & 6.8 & 3.7 & 1.7 & 3.8 & 2.4 \\
$\begin{array}{l}\text { Fiscal deficit (\% } \\
\text { of GDP) }\end{array}$ & -2.4 & -3.3 & -4.3 & -4.3 & -7.6 & -5.3 & -6.3 & $-5.6^{*}$ \\
$\begin{array}{l}\text { Average annual } \\
\text { inflation rate }\end{array}$ & 4.6 & 9.3 & 7.9 & 7.8 & 12.0 & 20.8 & 11.7 & 14.1 \\
$\begin{array}{l}\text { Current account } \\
\text { balance (\% of }\end{array}$ & 1.3 & -1.6 & -4.4 & -5.1 & -8.7 & -5.7 & -2.2 & 0.4 \\
GDP) & & & & & & & & \\
\hline
\end{tabular}

FY = fiscal year, GDP = gross domestic product.

* Latest estimates.

Source: Government of Pakistan, Pakistan Economic Survey 2010-11.

\footnotetext{
${ }^{3}$ This was also the main conclusion of the Panel of Economists set up by the Planning Commission in September 2008 (see Government of Pakistan, 2008).
} 
How well has Pakistan fared in its attempts to stabilize and bring about the necessary economic reforms? ${ }^{4}$ The simple answer to the question is that it has not and indeed the economy finds itself in the worse of both worlds-low economic growth and high double-digit inflation (see Table 2). True, the current account is in a small surplus, but this is a reflection of low growth and low investment. Also, Pakistan benefited in 2010/11 from favorable terms of trade (cotton, rice), which resulted in record exports but with a fall in global prices in cotton, this may turn out to be a short-term windfall.

How has this stagflation come about? The answer lies in the lack of consistent and, indeed, ineffective policy measures adopted both on the aggregate demand and aggregate supply side. On curbing aggregate demand as Table 3 and Figure 2 show, the main burden has fallen on investment, with both private and public sector investment falling drastically (see also Beaconhouse National University, 2011, p. 24). While the former reflects economic stagnation, lack of available energy, and a loss of business confidence due to the security and law-and-order situation, the latter is mainly because the adjustment burden has fallen on the Public Sector Development Program (PSDP), a "low-hanging fruit," as the government has been unable to curb its current expenditures.

Table 3: Domestic Absorption of Resources (1999-2000 Prices) (PKR billion)

\begin{tabular}{lcccccc}
\hline \multicolumn{1}{c}{ Resource } & $\mathbf{2 0 0 5 / 0 6}$ & $\mathbf{2 0 0 6 / 0 7}$ & $\mathbf{2 0 0 7 / 0 8}$ & $\mathbf{2 0 0 8 / 0 9}$ & $\mathbf{2 0 0 9 / 1 0}$ & $\mathbf{2 0 1 0 / 1 1}$ \\
\hline Consumption & 4,297 & 4,415 & 4,518 & 4,746 & 4,929 & 5,275 \\
Of which (private) & $(3,708)$ & $(3,883)$ & $(3,779)$ & $(4,246)$ & $(4,412)$ & $(4,719)$ \\
Investment (incl. stocks) & 924 & 1,043 & 1,114 & 965 & 916 & 915 \\
GCFG & 841 & 955 & 1,025 & 873 & 820 & 817 \\
Of which (public) & $(200)$ & $(262)$ & $(275)$ & $(236)$ & $(238)$ & $(2,29)$ \\
Total & 5,221 & 5,458 & 5,632 & 5,711 & 5,845 & 6,190 \\
\hline
\end{tabular}

GFCF $=$ gross fixed capital formation .

* Public investment based on Annual Plans (different issues). This is given in current prices and has been deflated using the implicit investment price deflator in the GFCF series above.

Source: Government of Pakistan, Pakistan Economic Survey 2010-11.

\footnotetext{
${ }^{4}$ Initially, the IMF found that progress under the SBA was satisfactory and-given Pakistan's peculiar circumstances-relaxed some of the conditionalities for the short run in view of the global recession and Pakistan's fight against insurgents. The agreement was augmented in August 2009 to SDR of USD10.66 billion and extended through December 30, 2010. However, lack of progress with economic reforms has led to an impasse in the first half of 2011 with the transfer of the next tranche put on hold.
} 
Figure 2: Private Investment and Consumption

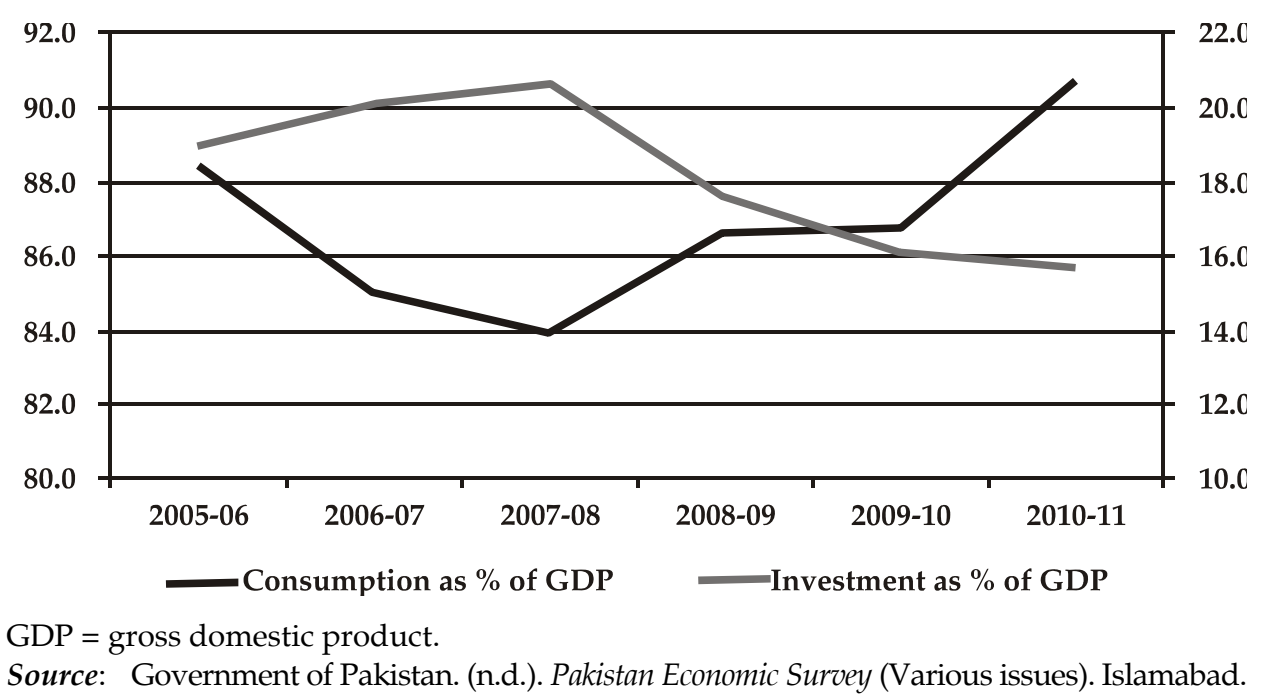

While in constant 1999-2000 prices both private and public investment declined by 20 percent between 2007/08 and 2010/11, total consumption in the same period increased by 14.3 percent and private consumption by 20 percent. The latter has clearly been driven to quite some extent by the steep increase in workers' remittances from abroad, which rose from USD6.5 billion in 2007/08 to an estimated USD11 billion in 2010/11. The increase in remittances is attributed to a shift in transmitting money from informal to formal channels as well as to the floods in summer 2010. However, this area needs further investigation.

The other injection in demand was the increase in government procurement prices for wheat, the staple food, from PKR450/40 kg to PKR625/40 kg in April 2008 and further to PKR950/40 kg in October 2008. The unprecedented increase in prices is believed to have significantly boosted aggregate demand in 2008/09, and has been seen as a major factor in further fuelling inflation, which touched over 20 percent in 2008/09.

Another boost to demand has been the increase in salaries of a hefty 50 percent by the federal government in the 2010/11 budget and a further 15 percent in the recent 2011/12 budget. These salary increases have to be followed not only by the semi-autonomous federal bodies but also by the provincial government and local bodies. At the same time, the government has not been able to fully remove fuel subsidies despite some increases in price, leading to a continuing high circular debt that has made worse the energy shortages faced by the economy (Box 1). 


\section{Box 1: Circular Debt}

The problem of circular debt has plagued the energy sector for more than three years, resulting in below-capacity power generation and consequent loadshedding. The nonpayment of electricity bills by federal and provincial government departments lies at the heart of the problem. Unable to recover their bills from the government departments, the power distribution companies fail to pay the power generation companies who, in turn, default on their payments to their major supplier, the Pakistan State Oil Company (PSO), with the oil refineries next in line. The delay in the payment of subsidy by the governmentwhich the distribution companies pass on to consumers-only makes the situation worse. Anecdotal evidence puts the size of the circular debt at about PKR350 billion. To address the problem of circular debt, the default by government departments on their electricity dues-the root cause of the problem-must stop immediately. This can be done by allocating a separate amount in the budget with which to pay electricity dues to the stakeholders concerned. Furthermore, the electricity distribution companies must be empowered to discontinue supply to defaulters regardless of their status. Resolving the problem of circular debt could mitigate the energy crisis to a significant extent, as experts reckon that it could bring 2,000-2,500 MW into the power system within a relatively short period.

Source: Amjad, Din, and Khawaja (2011).

\section{Ineffectiveness of Monetary Policy}

Why has inflation persisted despite a tight monetary policy stance by the SBP? We argue that a combination of factors have contributed to the ineffectiveness of monetary policy in curbing the rate of inflation. First, inflationary expectations remain entrenched due to supply disruptions caused by catastrophic floods, increase in electricity prices, and the government's continued reliance on borrowings from the SBP. Second, studies have shown that the interest rate channel of monetary policy transmission is weak in Pakistan. Since 2005, monetary policy has relied mainly on the interest rate channel. It is well known that monetary policy actions transmit their effects on macroeconomic variables with a considerable lag and with a high degree of volatility and uncertainty. The current monetary policy stance is silent on the issues of lags and the passthrough effect of the policy rate to inflation. There is evidence based on empirical analysis that the interest rate influences the rate of inflation with a lag of 12 to 18 months, and the magnitude of this impact is very small (Khan \& Qayyum, 2007; Qayyum, Khan, \& Khawaja, 2007). Indeed, some studies show that the relationship between the interest rate and rate of inflation is positive (Khan, 2007). 
Interest rate and inflation movements for the period 2007-10 is presented in Figure 3. It suggests a positive relationship between the interest rate and inflation, although clearly a number of other factors were at play. The coefficient of correlation is 0.688. It implies that the rising interest rate in recent years has had little impact on dampening inflation and there is no reason to believe that the situation has now changed.

Figure 3: Movements of Inflation and Interest Rate

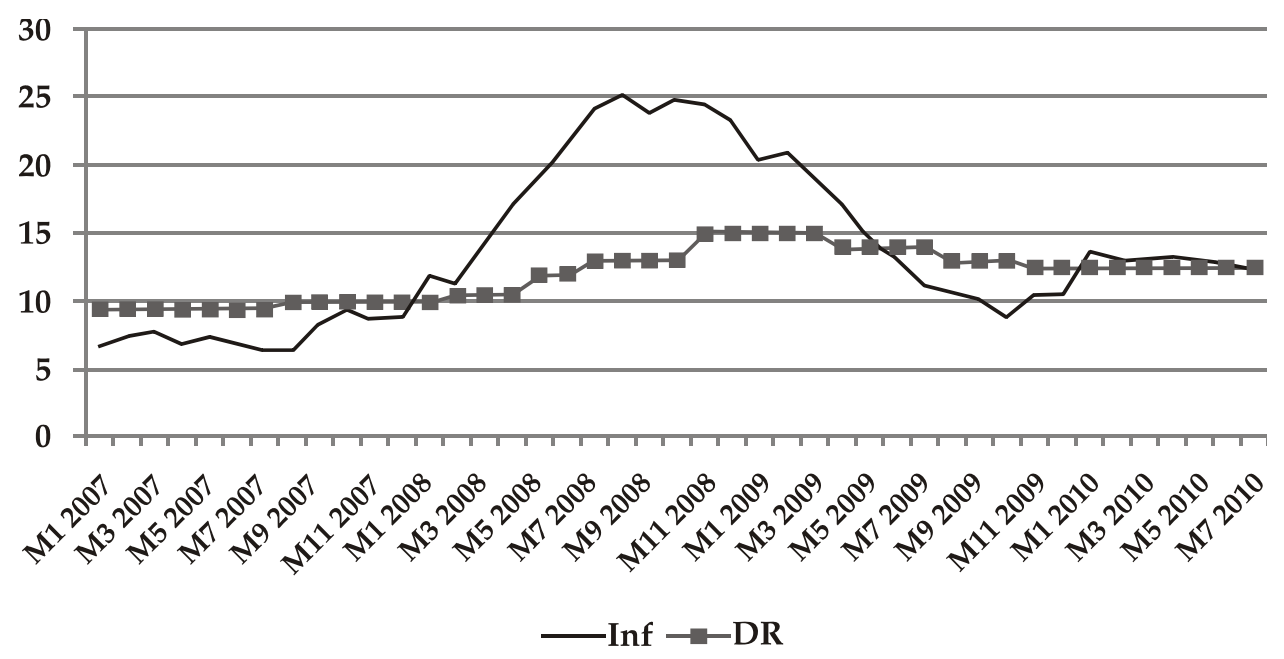

Source: Government of Pakistan. (n.d.). Pakistan Economic Survey (Various issues). Islamabad.

Third, the lack of coordination between fiscal and monetary policies has made monetary policy largely ineffective in controlling the rate of inflation. The government is borrowing beyond the agreed level from the SBP, and the SBP is not able to restrain this level of borrowing. The likelihood then is that the government would finance the higher deficit on account of higher interest payments by borrowing further from the central bank. Borrowing from the SBP injects liquidity into the system through increased currency in circulation. The impact therefore of a tight monetary policy stance is diluted with this automatic creation of money, which increases the money supply. International experience has shown that monetary expansion can be an important source of stagflation. For example, the excessive expansion of money is generally believed to be the main cause of the stagflationary episode of 1973-75 in the US. A similar monetary expansion preceded the second stagflationary episode of 1982 (Blinder, 1979). Sargent (1988) argues that monetary policy is less effective than is generally believed mainly because the size of the portfolio of government debts is beyond the control of the monetary authorities. The 
study predicts that "under a deficit spending policy it is impossible to run a noninflationary monetary policy" (p. 321).

It is generally expected that an increase in the interest rate would act as a deterrent to increased government borrowings from the central bank. In fact, it could further worsen the situation. The increase in the interest rate would increase interest payments on government debt, leading to an even higher fiscal deficit even if we take into account the higher profits of the SBP. During 2008/09, the increase in the discount rate increased the cost of borrowing from the treasury bills, Pakistan investment bonds, and national savings schemes. During the same period, an amount of PKR580 billion was spent on servicing domestic debt against the budgeted estimates of PKR459.1 billion. The fact is that easy recourse to increased borrowings from the SBP leaves little incentive for the government to put its fiscal house in order. In this situation, an increase in the interest rate can further worsen rather than improve the situation.

If the increase in the interest rate neither helps to reduce inflation nor appears to deter government borrowing, then the real hit is taken by the private sector. Higher interest rates increase the cost of borrowing for the private sector, which discourages the demand for private sector credit, thus stifling private investment and economic growth. There is a strong negative correlation between the discount rate and credit to the private sector (-0.84 over the period August 2009 to August 2010). When the monetary authority reduced the policy rate by 100 basis points from 14 to 13 percent in August 2009 and then further to 12.5 percent in November 2009 , credit to the private sector increased gradually during this period. In August 2010, the monetary authority again tightened monetary policy by increasing the policy rate by 50 basis points from 12.5 to 13 percent, which has again negatively affected credit to the private sector (see Figure 4). 
Figure 4: Interest Rate and Credit to Private Sector

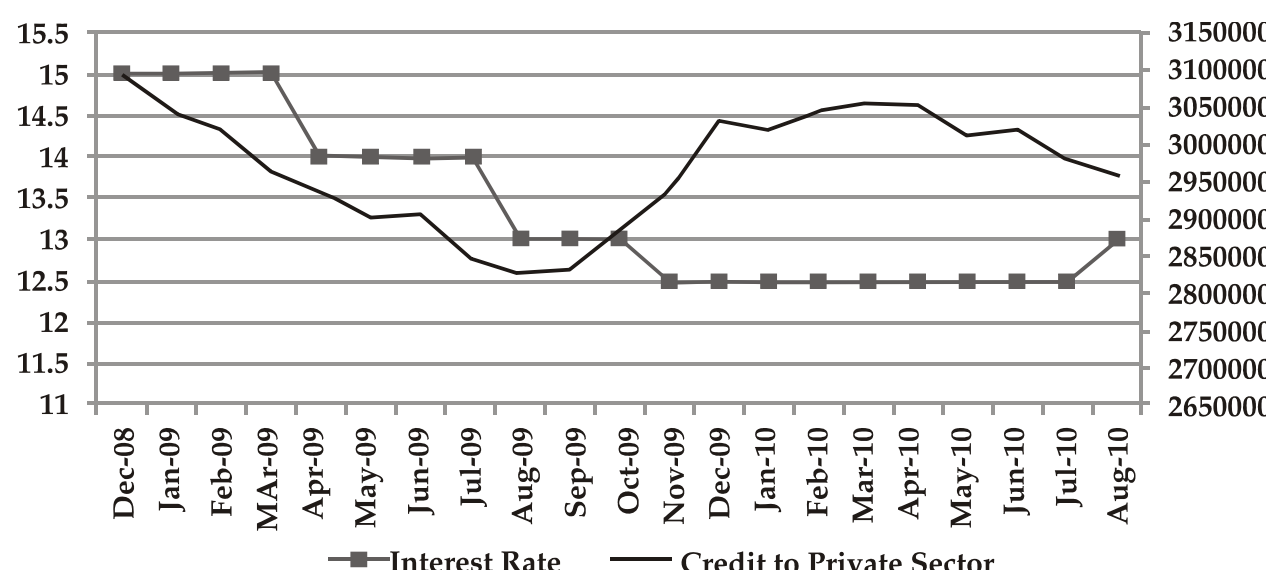

Source: Government of Pakistan. (n.d.). Pakistan Economic Survey (Various issues). Islamabad.

\section{Breaking Out of Stagflation ${ }^{5}$}

Breaking out of stagflation requires a coherent approach to stabilize the macroeconomy and address the binding constraints to the supply side to boost output on a sustained basis. To achieve these objectives, we suggest a four-point approach.

\section{i. Better Macroeconomic Management}

Prudent macroeconomic management is essential to pull the economy out of the current malaise. First, there is an urgent need to curb the monetization of fiscal deficit, which has contributed to inflationary pressures in the economy. Such a move would provide the necessary space for monetary policy to adjust so as to facilitate private credit without compromising price stability. Second, better policy coordination between the center and the provinces, especially after the $18^{\text {th }}$ Constitutional Amendment and the 7th National Finance Commission award, is essential to maintain macroeconomic stability.

Third, sectoral economic decisions (e.g., food prices) must be weighed carefully, keeping in view their impact on key macroeconomic variables. Past experience has shown that arbitrary decisions on key food prices helped stoke inflationary pressures in the economy that still show

\footnotetext{
${ }^{5}$ This section draws heavily on Amjad, Din, and Khawaja (2011).
} 
no signs of abating. ${ }^{6}$ Finally, a more effective utilization of foreign loans with a particular focus on channeling resources to addressing binding supply constraints, including energy shortages, would help revive the commodity producing sectors. There is room for better coordination between the Economic Affairs Division and the Planning Commission to ensure that the foreign resource envelope is utilized in line with the country's development priorities.

\section{ii. Achieving Fiscal Discipline while Reviving the Government's Role in Development}

Fiscal profligacy has been a root cause of macroeconomic imbalances. We argue that, whereas maintaining fiscal prudence is absolutely essential, it is also necessary to revive the government's role in the development process. To achieve fiscal discipline, concerted efforts are needed both to rationalize public spending and to reform the taxation system. In particular, all but targeted subsidies must be eliminated, the PSDP must be reprioritized to concentrate resources on development projects that are critical for the country's competitiveness, and the massive losses of state-owned enterprises must be plugged to free up resources to finance the country's development needs. These measures need to be complemented by a freeze on nondevelopment spending that would encourage the public sector to adopt austerity measures, thus allowing more space for development spending.

On the revenue generation front, the need to generate more revenues cannot be overemphasized, given the abysmally low tax-to-GDP ratio. The imposition of RGST has been stalled due to lack of political will. We believe that introducing RGST is essential to fully tap the revenue generation capacity as well as to help the process of documentation in the economy. To widen the tax base, all sources of income-including agriculture, services, and real estate-must be brought under the tax net. In addition, there is significant potential for generating tax revenues at the provincial level, given that the contribution of the provinces to total tax revenues is just around 10 percent. The provinces could be encouraged to generate more tax revenues if the transfer of funds to the provinces under the $7^{\text {th }}$ National Finance Commission award was linked to the provinces' taxation efforts while taking into account the revenue generation capacity of each.

\footnotetext{
${ }^{6}$ An example is the massive increase in the wheat procurement price from PKR450/40 kg in 2007 to PKR950/40 kg.
} 
It must be emphasized here that the restoration of fiscal balance must not come at the cost of critical development spending by the public sector. Unfortunately, the current fiscal squeeze meant to contain the fiscal deficit has largely been borne by the PSDP while nondevelopment expenditures have not seen any significant reductions. Cuts in development spending, including on critical physical infrastructure, will have adverse implications for the country's long-term competitiveness. What is needed here is a strategy to rationalize public spending to avoid across-the-board cuts in development expenditures, and to ensure that scarce development funds are channeled into key sectors such as energy and more labor-intensive activities to help promote job creation and boost economic growth. Furthermore, public spending on physical infrastructure would not only strengthen the country's long-term competitiveness, it would also help in poverty alleviation, as research has shown that spending on infrastructure is the most pro-poor public expenditure (see Arif \& Iqbal, 2009).

\section{iii. Prudent Monetary Management to Spur the Private Sector}

The current monetary policy has not been helpful in either ensuring macroeconomic stability or reviving growth in the economy. There are some encouraging signs that point out that there is some scope for monetary policy to adjust toward helping the revival of the private sector. First, the government is reining in its borrowings from the SBP. This move should enable the central bank to contain monetary expansion within the desired limits, thus providing the necessary space for monetary policy to be more accommodating toward shoring up economic activity. Second, the exchange rate remains stable and is underpinned by favorable external account indicators, including a surge in remittances, a pickup in exports, and a healthy foreign exchange reserves position. Third, according to the Pakistan Institute of Development Economics' latest business barometer survey (April 2011), there are distinct signs of "green shoots" in the economy. The survey reported a modest increase in business volumes by almost half the respondents during the second half of 2010, and firms were optimistic about growth in their business volumes in the future.

Recent data shows that growth in the large-scale manufacturing sector, though sluggish, remains positive. There is ample unutilized capacity and growth could quickly accelerate with a significant boost coming from an improvement in rural incomes triggered by an increase in commodity prices. The above factors point out that the private sector is expected to respond positively to an appropriate adjustment of monetary policy, and that the latter move is not likely to imperil price or exchange rate stability. 


\section{iv. Social Safety Nets}

The combination of persistently high inflation and low growth is a recipe for declining purchasing power, joblessness, and poverty. In this scenario, well-designed social safety nets could ease the pain of adjustment for poor households during the time the economy takes to revert to robust growth with price stability. Whereas the BISP has proved an effective tool in poverty alleviation, its coverage remains limited. We believe that some fiscal space could be created to widen the scope of income transfers under the BISP by cutting waste in nondevelopment spending and by minimizing the losses of public sector enterprises. In addition, more effective and judicious utilization of zakat funds would be instrumental in providing the necessary support to the poor and vulnerable groups.

\section{Concluding Remarks}

This article has identified the factors underlying the current episode of stagflation, and has spelled out a set of policy measures to pull the economy out of this quagmire. We have argued that, while the economy remains beset by structural weaknesses and lack of political resolve to undertake critical economic reforms, the major cause of the current stagflation can be traced to supply shocks that have resulted in output contraction with a concomitant increase in the price level. Buoyant demand on the back of high fiscal deficits, strong growth in remittances, high support prices for cereals, and a significant increase in public sector wages has only added to the inflationary pressures. Furthermore, macroeconomic stabilization policies have been unsuccessful in curbing the rate of inflation, due mainly to the lack of coordination between monetary and fiscal policies.

We have stressed that, whereas achieving macroeconomic stability is essential, it is equally important to address the binding supply-side constraints, including the crippling energy shortages. With this in view, we have outlined a four-point strategy that emphasizes better macroeconomic management, achieving fiscal discipline while reviving the role of the government in the development process, prudent monetary management to spur private activity, and social safety nets. Pakistan's economy has shown resilience in the past and it is hoped that, with the right policies in place, economic growth can be revived on a sustained basis in an environment of macroeconomic stability. 


\section{References}

Ahmad, M. (2011). An economic crisis state? In M. Lodhi (Ed.), Pakistan: Beyond a crisis state. Karachi, Pakistan: Oxford University Press.

Amjad, R., \& Din, M. (2010). Economic and social impact of global financial crisis: Implications for macroeconomic and development policies in South Asia. Islamabad: Pakistan Institute of Development Economics.

Amjad, R., Din, M., \& Khawaja, I. (2011). PIDE budget viewpoint 20112012: Breaking out of stagflation-A three-point strategy. Islamabad: Pakistan Institute of Development Economics.

Arif, G. M., \& Iqbal, N. (2009). Infrastructure and poverty nexus: The case of rural Pakistan. In Socioeconomic Challenges faced by Pakistan: Proceedings of the National Conference. Islamabad, Pakistan: International Islamic University.

Barsky, R. B., \& Kilian, L. (2002). Do we really know that oil caused the Great Stagflation? A monetary alternative. In Macroeconomics Annual 2001. Cambridge, MA: National Bureau of Economic Research.

Beaconhouse National University. (2011). Fourth annual report on the state of the economy. Lahore, Pakistan: Institute of Public Policy.

Blinder, S. (1979). Economic policy and the Great Stagflation. New York, NY: Academic Press.

Brunner, K., Cukierman, A., \& Meltzer, A. H. (1980). Stagflation, persistent unemployment and the permanence of economic shocks. Journal of Monetary Economics, 6, 467-492.

Bruno, M., \& Sachs, J. D. (1979). Supply vs. demand: Approaches to the problem of stagflation (Working Paper No. 382). Cambridge, MA: National Bureau of Economic Research.

Government of Pakistan. (n.d.). Pakistan Economic Survey (Various issues). Islamabad.

Government of Pakistan. (2008). Panel of economists: Interim reportEconomic stabilization with a human face. Islamabad, Pakistan: Planning Commission. 
Haque, I. (2010). Pakistan: Causes and management of the 2008 economic crisis (Global Economic Series No. 22). Penang, Malaysia: Third World Network.

International Monetary Fund. (2008). Pakistan: Request for stand-by arrangement (Country Report No. 08/364). Islamabad, Pakistan: Author. Retrieved from www.imf.org/external/pubs/ft/scr/2008/cr08364.pdf

Khan, M. A., \& Qayyum, A. (2007). Trade, financial and growth nexus in Pakistan. Economic Analysis Working Papers, 6(14).

Khan, S. (2007). Channels and lags in effects of monetary policy's transmission mechanism: A case of Pakistan. Unpublished PhD dissertation. Pakistan Institute of Development Economics, Islamabad.

Qayyum, A., Khan, S., \& Khawaja, M. I. (2007). Interest rate pass-through in Pakistan: Evidence from transfer function approach. Pakistan Development Review, 44(4), 975-1001.

Sargent, T. J. (1988). The role of monetary policy under US institutions. In A. Anderson \& D. J. Bark (Eds.), Thinking about America: The United States in the 1990s (pp. 311-322). Stanford, CA: Hoover Institution. 